REVIEW ARTICLE

\title{
PROUD SHOES: BLACK FAMILY HISTORY IN AUSTRALIA
}

\author{
Niel Gunson
}

Black family history is a relatively new genre and as such is one of the more positive manifestations of the new school of Black history. ${ }^{1}$ It is the history of people of mixed origins who identify themselves socially and politically with their black-skinned ancestors. They call themselves Blacks and are known as such in the United States, South Africa and, to a lesser extent, Australia. Their family history differs from African, Aboriginal or Melanesian family history in that the families concerned have had their life crises in the midst of a society alien to their own cultural origins. Black family history has much in common with the family history of other ethnic minority groups except that colour consciousness, prejudice and discriminatory policy have been far more evident. It further differs from European or White American and Australian family history in its freedom from social pretension. European family history began as the history of great families, was then shared by the landed classes, and only in the nineteenth and twentieth centuries became the preoccupation of the middle and lower middle classes. In the modern period, sociological studies have been made mainly of lower class families. Black family history does not fit easily into this class categorisation for its distinguishing characteristic is ethnic pride irrespective of the class status and professionalism achieved by members of the families concerned.

It is significant, then, that the pioneer study in this genre published in 1956 was entitled Proud shoes: the story of an American family. ${ }^{2}$ The author, Pauli Murray, graduated from Hunter College, Durham, North Carolina in 1933. Member of a professional family (her father was a school principal and her mother a graduate nurse) Miss Murray suffered much from discrimination in pursuit of her distinguished career. In 1938 she was rejected as a graduate student at the University of North Carolina because of her race and in 1944 was rejected by Harvard Law School (having won a scholarship to go there) because of her sex. Notwithstanding, she obtained a master's degree in law from the University of California at Berkeley and in 1965 she was awarded her doctorate at Yale. She was ordained to the priesthood of the Episcopal Church in Washington Cathedral in January 1977.

Dr Murray thought of writing a family memoir as early as 1933 intending merely to entertain and instruct her small nieces and nephews.

What changed my direction, and gave me a motive so compelling that I interrupted my law practice for four years to devote myself full time to researching and writing Proud Shoes, was the political and social climate of the 1950s. The civil rights movement was gathering momentum .... anyone who championed a liberal cause was vulnerable to the charge of disloyalty ... As a civil rights activist fighting against racial segregation when challengers of segregation policy

1 Black history, like gay history and women's studies, is one of the new sub-disciplines deriving from the civil rights and related movements and is largely concerned with themes such as resistance and social oppression. Black history as such in Australia is only one facet of Aboriginal history and is clearly differentiated by its socio-political content and message. A typical Australian example is Robinson and York 1977.

2 Murray 1956. I am indebted to Dolores Janiewski of Washington for introducing me to Proud shoes. Harper \& Row classified Murray 1978 as autobiography rather than family history, yet Rubin 1981 does not mention Murray. Family history is here understood in its traditional sense (i.e. the history of individual families) and not as the new discipline developed by sociologists and demographers which is concerned with the impersonal history of family units. 


\section{ABORIGINAL HISTORY 1981 5:2}

were few and defeats were customary, I found it imperative to declare my American heritage. Not Communism, but the ideals and influences within my own family had made me a life-long fighter against all forms of inequality and injustice. ${ }^{3}$

So Black family history was born in a spirit of ethnic pride and assertiveness in 1956. Pauli Murray stressed the fact that her story was not unique, that the 'multi-racial origins of both blacks and whites' were realities that could be ignored but 'not wholly discounted'. ${ }^{4}$ She wrote her story before the polarisation of the races in America and the emergence of the Black Consciousness movement which dominated race relations in the 1960s.Proud shoes, important and well-written as it was, excited little public interest in 1956.

In 1965 another Black author, Alex Haley, began work on a similar exploration of his family past which took twelve years to complete. Roots, ${ }^{5}$ which first appeared in the American Bicentennial Year 1976, was an immediate best-seller coinciding as it did not only with a revival of interest in American history but also with the aftermath of a crusade for social justice. Roots was, in fact, praised for doing what Proud shoes had already achieved twenty years previously. A new edition of Proud shoes appeared in 1978, but it was Roots which captured the public imagination, going through many printings and being dramatised for television audiences throughout the world.

In one respect Roots went further than Proud shoes in that Haley took his narrative back into Africa, opening his saga with the birth of Kunta Kinte (later an American slave) in West Africa. ${ }^{6}$ Pauli Murray also explored her African cultural roots in Ghana in 1960-61. This 'cleared [her] vision of whatever negative stereotypes had blurred [her] understanding of the African background'; it also confirmed her in her essential Americanness. ${ }^{7}$

Both Proud shoes and Roots are based on authentic family material. Both authors spent many hours perusing records and checking detail. Both relied heavily on the memories and folk-memory of elder relatives. Indeed, it is almost possible to believe that the real authors were the elderly aunts and cousins as they told anecdotes from their rockers, checked the manuscript drafts, and in Haley's case, even seemed to direct his researches after death.

It seemed to me then, it seems to me today, that I was a conduit, no more, enacting my particular role in a quest that would result in a book, that could play a positive role within a society which on a worldwide scale seems all too much afflicted with a sense of what might well be termed rootlessness. ${ }^{8}$

For Haley there was and is a real belief that he was writing for his ancestors in the spirit world; he tells of his cousin Georgia going 'up there' - 'as she used to say, to be with grandma, and Aunt Liz, and Aunt Till, and Aunt Plus, and all the others, all of them "settin' up there watchin' " me, to see what I was going to do'. ${ }^{9}$ Murray is less mystical in this respect but her tribute to her aunts is just as real.

My great regret is that none of my aunts lived to read the published result. At least, in their closing years, they were part of its making. They shared in the findings of my field research and had a sense of significant undertaking which made them feel productive to the end. I know the story has a flavor which comes from the wealth of human detail they gave me; it could have come from nowhere else. ${ }^{10}$ 


\section{REVIEW ARTICLE}

Both authors were able to illuminate the social history of their country through the records of real but otherwise little known people. Murray's was the more scholarly approach with its greater attention to factual incident and detail. Both authors admit to literary licence. Murray states that 'in a few instances' she 'took liberties and drew conclusions which the facts seemed to justify'.11

It is an attempt to give a coherent account of my forebears, based on tales told to me and facts discovered in my search of the historical record. I was able to confirm enough of the family stories to trust the credibility of our oral traditions. Throughout the narrative, I tried to distinguish between the facts and the legends which could not be substantiated.

On the other hand, Haley's account is historical fiction; only the outline has any factual base in the records. Both reconstruct conversations but Haley's narrative is dominated by the conversational form in full idiom.

The popularity of Roots led to a general quickening of interest in family history. ${ }^{12}$ Appearing as it did in a climate sympathetic to Black consciousness, negritude, and equal rights, Roots achieved an acceptance of the integrity of Black family history. Indicative of this was the recognition of 'a Black heritage' by the Mormons whose church had long held aloof from admitting Blacks to the priesthood. ${ }^{13}$ As early as 1971 an organization for Black Mormons known as the Genesis Group was formed, but it had a chequered history until 9 June 1978 when the Mormon leader, Spencer W. Kimball, announced that he had received a divine revelation that 'all worthy male members of the Church could hold the Priesthood of God - including Black men'.14 The president of the Genesis Group, Ruffin Bridgeforth, was ordained the first Black High Priest and rose rapidly in the hierarchy. The first Black couple were married in the Salt Lake Temple in June 1980.

In August 1980 Alex Haley was the principal guest speaker at the Second World Conference on Records hosted by the Genealogical Society of Utah at Salt Lake City, and attention was given to the collection of Black family records and genealogies for the first time. ${ }^{15}$ One outcome of this was a new Mormon policy: to collect the oral family traditions of the Australian Aborigines.

Black family history is as relevant in Australia as it is in America. It is important for Aboriginal authors, as it was for Dr Pauli Murray, to show that their interest in social justice and basic human rights has no necessary connection with imported ideologies but stems naturally from their Australian experience. It is even more important for them to walk with proud shoes. Until recently most Aborigines were in the same position as Black families in America before 1956: while many 'had a rich oral tradition which they shared privately, few had the time or incentive to develop formal genealogies or to write family histories' ${ }^{16}$ Certainly the older members of families had preserved the lore and many anthropologists had enough information to construct elaborate descent charts, but no one had attempted a narrative history based on the genealogical links.

The first Aboriginal family history to be published was usually condensed into a few introductory pages in biographies and autobiographies of distinguished Aborigines. The accounts ranged from several pages in Charles Perkins's $A$ bastard like me, to two chapters in Mavis Clark's biography of Sir Douglas Nicholls. ${ }^{17}$ This material hardly qualifies as Black family history. In most of these accounts there has been little sense of 
continuing family values and the most substantial narratives have usually been written by white biographers. They have contained little social message or a real desire to trace 'roots'.

In 1977, the year after the publication of Roots, Faith Bandler produced a fictionalised account of her own father's origins in the New Hebrides and his experiences in the Queensland labour trade. Her book, Wacvie, purported to be a piece of historical detection similar to Roots. ${ }^{18}$ Although Mrs Bandler did not explore Aboriginal origins in Wacvie this work heralded Black family history in Australia. It was followed by another fictionalised account of Aboriginal family life, Karobran. The story of an Aboriginal girl by Monica Clare, published posthumously in 1978. Hailed as the first novel by an Aboriginal woman, Karobran had been written before 1972 when the manuscript was offered to the Federal Council for the Advancement of Aborigines and Torres Strait Islanders. ${ }^{19}$ Although not Black family history as such the story shared the social character and pride of that genne which may well serve as the guideline for authentic Aboriginal family histories. As Faith Bandler wrote of Karobran in her preface to the book in 1977 it clearly portrayed the "uncertainty, humiliation and degradation endured by Black Australians in and out of the work force'. ${ }^{20}$ She pointed out that 'the struggle of the Blacks to keep their families united epitomises the whole sad history of Black and White relationships in Australia'. The only other Aboriginal family records to be published before 1980 have been purely genealogical. ${ }^{21}$

Phillip Pepper's You are what you make yourself to be: the story of a Victorian Aboriginal family 1842-1980 is a fine example of Black family history in Australia and either shares or varies many of the characteristics of the American prototype. First, it is a first-person record by an Aboriginal. In this case Phillip Pepper has been assisted by his researcher and friend, Tess De Araugo, ${ }^{22}$ a successful combination similar to that between the professional Black authors and their older relatives steeped in oral history. The conversational idiom of Roots and Proud shoes finds parallels in Pepper's colloquial narrative. The editor's interspersed gloss, although happily wedded to Pepper's firstperson account, is sometimes unsatisfactory in that it ignores some useful sources but this does not detract from the overall effect of seeing events through Aboriginal eyes.

The history, like all good family histories, reflects the times and events in the world at large. Just as the American authors were able to relate the human drama to great issues in American history (particularly those which affected them most such as slavery and the Civil War, as well as local events in North Carolina, Delaware and Virginia) so Pepper's narrative is acted out in terms of both national and local events. Tribal wars, mission station life, discriminatory legislation, the First World War, soldier settlement and the Great Depression are looked at with the same subjectivity as family celebrations and the passing of colourful or sympathetic characters. Family history can be at once extremely personal and representatively national, a point confirmed by the excellent illustrations. Just as Pauli Murray derived her essential Americanness from the North Carolina experience of her family, so Pepper's identity stems from the Gippsland experience.

There is, too, a religious parallel; not essential to the genre, but a source of motive. Pauli Murray wrote:

If Grandfather had not volunteered for the Union in 1863 and come south three years later as a missionary among the Negro freedmen, our family might not have walked in such proud shoes and felt so assured of its place in history. We might have fought our battles with poverty and color troubles, thinking of ourselves as nobodies or not thinking of ourselves at all, dying out with nothing

19 Clare 1978, Wild cat falling by Colin Johnson (1965) is regarded as the first novel by an Aboriginal.

20 Preface dated 16 September 1977 to Clare 1978:ix.

21 For example Mollison and Everitt 1978.

22 Pepper 1980. 
to remember of us except a few census figures... What he attempted - far more than what he finally achieved - made him our colossus and beacon light. Because of him we felt that we belonged, that we had a stake in our country's future, and we clung to that no matter how often it was snatched away from us. ${ }^{23}$

So also Phillip Pepper looks back to his grandfather Nathaniel Pepper, who belonged to the Wotjoballuk tribe of the Wimmera. He had the distinction of being the first tribal Aboriginal to be baptised in Victoria; he served as an evangelist to his people until his death in 1877. Mr Pepper was responsible for organising a memorial service at Nathaniel's grave in 1977. The Moravian missionary's granddaughter told him that she was 'thinking all the time about how over a hundred years ago our grandfathers had such a shining faith and that it was something she felt we can't hold a candle to, but we just have to keep on trying. And she was right' ${ }^{24}$ In the modern religious affiliations there is an interesting contrast. While Pepper's family moved from a conservative Presbyterian Moravian background to the less formalised isboriginal Evangelical Fellowship, Pauli Murray's family with its liberal Quaker and Presbyterian associations finally embraced the Episcopalian faith of her Southern slave-owning ancestors.

While Phillip Pepper's book lacks the literary finesse and sustained narrative of Murray's book (which deserves to become a classic of its kind), it has qualities which will do much to convince other Australians - both Aboriginal and European - of the richness and diversity of the 'Black' heritage. Above all, a quiet pride pervades Pepper's story, a dignity commensurate with the motto which he chose for his family history; 'You are what you make yourself to be'. This piece of home-spun Aboriginal lore echoes the wisdom of the Upanishads: 'As a man acts, as he behaves, so does he become'. ${ }^{25}$ One is reminded of the words written in 1934 which inspired Pauli Murray' with the title of her book:

Here is a new voice - and the voice of a new generation . . . its clear incisive speech cuts deep into native ground. Here is somebody, walking in [Australia] in proud shoes. ${ }^{26}$

S.M. Kelly's Proud heritage, published by Artlook Books, is aptly named; it is the family history of Mrs Clara Jackamarra of Broome, who grew up on her father's station Changergoodering or Thangoo in Western Australia. The story has parallels with Pauli Murray's experience. On the negative side one reads between the lines that Mrs Jackamarra has been the victim of discrimination. On the positive side she shares with Pauli Murray a pride in the quality and achievements of her European ancestors. The book's origin is her quest for recognition as a descendant of the prominent Australian pioneer John Septimus Roe (1797-1878), naval officer, surveyor and explorer who arrived in New South Wales in 1817 and who was progenitor of one of Western Australia's founding (English) families in 1829. Her mother Mary Budjinka, of Aboriginal and Asian descent, was de facto wife of George Harriot Roe, an outstanding man in his own right. The three daughters and son, like other station children in the district, were 'well-spoken and well brought up', ${ }^{27}$ but normal homestead life ended when they were sent to a mission school at Beagle Bay in 1909-12.

As with Phillip Pepper's story the actual compiler is a friend, in this case Sheila M. Kelly. The first chapter tells of Clara Jackamarra's search and features correspondence which highlights the negative response she received. The second chapter is a brief family history prefaced by charts of the Roe family and its alliances with other Australians of Aboriginal, European, Afghan, Chinese and Malay descent. The third chapter consists of Mrs Jackamarra's recollections told in the first person. In her own words she is 'proud to be black ..., proud to be white . . .. It is this double pride in being descendants of the 'original proud owners of the country' and of the European pioneers

Brihadaranyaka Upanishad IV, iv, 5 in Zaehner 1966:71.

26 For Stephen Vincent Benet's original words see Murray 1978:viii.

27 Kelly 1980:55. 


\section{ABORIGINAL HISTORY 1981 5:2}

which is being newly discovered ${ }^{28}$ Australians of mixed descent have every cause for frustration and bitterness in their own experience. Not only has traditional land been alienated from them but in many cases, such as that of Clara Jackamarra's family, Aboriginal children have been excluded from the estates of their prosperous European forebears, and have received no financial or other legacy comparable to that claimed by white children. Mrs Jackamarra displays no bitterness but she hopes that a few acres of her old home Thangoo will be set aside as a permanent trust for her father's descendants. ${ }^{29}$ Like Proud shoes her story demonstrates that it is experience in Australia and not imported ideologies which inspire the Aboriginal search for justice, equality and recognition. It would be fitting if one of G.H. Roe's descendants or an Aboriginal of similar descent could be sufficiently inspired by this story to write a saga of Black family history which would explore both sides of the heritage. Such narratives might assist the achievement of reconciliation and equal justice by 1988, when the much vaunted Bicentennial celebrations take place.

\section{AUSTRALIAN NATIONAL UNIVERSITY}

\section{BIBLIOGRAPHY}

Bandler, Faith. Wacvie Adelaide, 1977.

A brief history of the Genesis Group. Duplicated leatlet. [Salt Lake City, 1980].

Clare, Monica. Karobran: the story of an Aboriginal girl [Sydney], 1978.

Clark, Mavis Thorpe. Pastor Doug: the story of an Aboriginal leader. Melbourne, 1965.

Douglas, Norman. 'The sons of Lehi and the seed of Cain: racial myths in Mormon scripture and their relevance to the Pacific Islands', Journal of Religious History, 8(1), 1974:90-104

Haley, Alex. 'Family - a humanizing force'. Address to the Second Worid Congress on Records, Salt Lake City. August 1980 in The Church of Jesus Christ of Latter-Day Saints. Personal and family history. Supplementury malerial Salt Lake City, 1980, n.p.

- - Roots London, 1977, 1st Eng. ed. (10th printing of paper ed. 1979).

Kelly, S.M. Proud heritage. Hay Street East, Western Australia, 1980.

Mollison, Bill and Everitt, Coral. 'Tasmanian Aboriginal genealogies (to fourth generation)' parn 2 of Tasmaniun Aborigines and their descendants (chronology, genealogies and social data) ed by Phil Hackett. Hobart, 1978.

Murray, Pauli. Proud shoes: the story of an American family. New York, 1956. (New ed. New' York, 1978).

Pepper, Phillip. You are whal you make yourself to be: the story of a Viatorian Aboriginal familv 1842-1980. Melbourne, 1980.

Perkins, Charles. A bastard like me Sydney, 1975.

Robinson, Fergus and York, Barry. The black resistance: an introduction to the history of the Aborigines' struggle against British colonialism Camberwell, Victoria, 1977.

Rubin, Steven J. 'Ethnic autohiography, a comparative approach', Journal of Ethnic Studies, 9(1), 1981:75-79.

Zaehner, R.C. ed Hindu Scriptures London, 1956. 